\title{
Ros og Ris
}

\section{Af Gustav Albeck}

Jens Lyster: Om Grundtvigs "Sov sødt barnlille og andet godt $i$ en updagtet bønnebog fra 1847"i Hymnologiske Meddelelser, udgivet af Salmehistorisk Selskab og Nordisk Institut for Hymnologi, 18. drgang, 1989,. nr. 3.

Forfatteren har i Det kgl. Bibliotek (og Universitetsbiblioteket) fundet en lille samling "Morgen- Bord- og Aftenbønner, udgivne af en Forening af Præster og Skolelærere i Kjøbenhavn" (1847) og især studeret bønnebogens "Anhang", der indeholder fire sange/salmer: "Sov sødt Barnlille", "Saa vil vi nu sige hverandre Farvel", "Jeg er af ringe Bondestand" og "Frygt mit Barn den sande Gud."

Lyster oplyser, at bogen kom i 2. oplag 1849 og i 3. oplag 1855 og altså har været ret udbredt, men at de næunte 4 salmer og sange "har unddraget sig hymnologernes opmærksomhed". Udgiverne af bønnebogen kalder sig i alle 3 oplag "en Forening af Præster og Skolelærere", og Lyster forsøger med kritisk forsigtighed at identificere dem. Med sikkerhed fastslår han, at de "må have været i direkte kontakt med Grundtvig og kredsen omkring ham".

Som det fremgår af titelen på Lysters afhandling, er det bønnebogens gengivelse af "Sov sødt Barnlille", som især har vakt hans interesse. Han når ved komparativt studium af de mange - ofte små - varianter i de overleverede textformer af salmen til den konklusion, at udgiverne af den omhandlede bønnebog fra 1847 "har benyttet et i dag ukendt håndskrift, muligvis af Grundtvig selv".

Denne kendsgerning kunne måske tyde på, at begyndelseslinjerne til strofe 5 med ordlyden:

Da alle de Døbte

I Jesu Navn kiøbte

er de oprindelige - og ikke, som en anmelder af bønnebogen (i Dansk Kirketidende 1848, nr. 50) formoder, beror på en trykfejl, således at den oprindelige text skulle være:

Da alle de Kiøbte

I Jesu Navn døbte

Denne textform forekommer unægtelig allerede i et brev fra Grundtvig af 6. august 1844 (til Peter Rørdam) og kan være den oprindelige. Men Lyster giver i en kyndig analyse gode grunde for, at også textformen i bønnebogen skyldes Grundtvig, eftersom det "helt igennem er Apokalypsens billeder ... der vælter sig ind på Grundtvig og giver ham denne strofe". 


\section{5}

I 2. udgave af "bønnebogen" er rækkefølgen af rimordene "Døbte" og "kiøbte" ændret, og Lyster argumenterer bravt for, at Grundtvig har foretrukket denne ændring af texten.

Jeg kan ikke være uenig med Lyster, når han afsluttende hævder, "at der er skellig grund til at betragte teksten i bønnebogens førsteudgave som et tidligt og hidtil ukendt led i Grundtvigs udvikling af vuggesangens tekst". Derimod er jeg ikke så lidt forundret over den iver, hvormed han svinger tugtens ris over udgiverne af "Sangværket" og hævder, at Grundtvigforskningen (sic!) ikke kan bruge E. Maus "anvendelse af Grundtvigs salmer til noget" - og insinuerer at "de anonymt udgivne "Morgen- Bord- og Aftenbønner" (1847) ikke "har kunnet tages alvorligt af seriøst arbejdende Grundvigforskere" (sic!), fordi bønnebogens udgivere ikke "hørte til Grundtvigs sande venner"!

Man spørger sig selv om, med hvilken ret han med sin pisk langer ud efter Grundtvigforskningen $\mathrm{i}$ al almindelighed, når han fortsætter sin kritik af Sangværkets ny-udgivere med følgende grausame Salbe:

"Det forstår sig, at der gælder særlige principper for det helt specielle speciale inden for forskningens verden, der hedder Grundtvigforskningen, hvor medlemskab af en bestemt vennekreds og måske endog venskabets temperatur spiller en afgørende rolle for tekstvidners troværdighed og relevans"!

Det forekommer mildest talt forbavsende, at en så kritisk og kundskabsrig forsker som Lyster uden forbehold sætter Grundtvigforskningen som helhed under en uberettiget anklage. 